\title{
Screening of Sorghum Varieties for Papad Preparation
}

\author{
Butti Prabhakar*, D.R. More, P. Srilatha and Chavan Ramesh Fulchand \\ College of Food Technology, Vasantrao Naik Marathwada Krishi Vidyapeeth, Parbhani, \\ Maharastra, India \\ *Corresponding author
}

\begin{tabular}{|c|c|}
\hline & A B S T R A C T \\
\hline & \multirow{4}{*}{$\begin{array}{l}\text { The study was conducted in the laboratory of the Department of Food } \\
\text { Trade and Business Management, College of Food Technology, VNMKV } \\
\text { Parbhani, to screening of sorghum varieties for papad preparation. Papads } \\
\text { were prepared from different sorghum varieties and analyzed for proximate } \\
\text { composition, physico-chemical analysis and organoleptic evaluation. The } \\
\text { result revealed that moisture, protein, fat, ash and total carbohydrate } \\
\text { content in the Sorghum papad prepared from Parbhani Moti sorghum } \\
\text { variety were found in the range of } 9 \text { to } 9.25 \%, 8.39 \text { to } 12.64 \%, 0.88 \text { to } 1.05 \\
\%, 0.54 \text { to } 1.27 \% \text { and } 76.77 \text { to } 80.21 \% \text { respectively. Parbhani Moti } \\
\text { sorghum variety was selected among five sorghum varities based on } \\
\text { organoleptic evaluation of papads. }\end{array}$} \\
\hline $\begin{array}{l}\text { Sorghum varieties, } \\
\text { papad, Physico- } \\
\text { chemical and } \\
\text { Sensory } \\
\text { characteristics. }\end{array}$ & \\
\hline Article Info & \\
\hline $\begin{array}{l}\text { Accepted: } \\
\text { 17 June } 2017 \\
\text { Available Online: } \\
\text { 10 July } 2017\end{array}$ & \\
\hline
\end{tabular}

\section{Introduction}

Sorghum [Sorghum bicolor (L.) Moench] popularly called as jowar, is the "king of millets" and is the fifth in importance among the world's cereals after wheat, rice, maize and barley (Anglani, 1998; Awika and Rooney, 2004). Great advantage of sorghum is that it can become dormant under adverse conditions and can resume growth after relatively severe drought. The future promise of sorghum in the developed world is for wheat substitution for people with celiac disease or allergies to gluten (Bogue and Sorenson, 2008). U.S. Department of Agriculture Foreign Agricultural Service USDA states world sorghum production is forecasted to reach to 65.2 million tons in 2016/17 season.
Papad is indigenous traditional snack item with thin wafer like product prepared from variety of ingredients.

Apart from value addition by processing to traditional products from these grains, development of newer products offers variety, convenience, quality, cost- efficiency and scope for increasing the nutritional value (Veena et al., 2012).

Generally, cereal papads are prepared from gelatinized flour prepared of soaked grains. In addition to legume based products, papads are also made from tapioca, sago, jackfruit, gelatinized rice flour and wheat flour (Arya, 1990). 
Materials and Methods

\section{Raw materials}

Sorghum [Sorghum bicolor (L.) Moench] varieties like Parbhani Moti, Parbhani Jyoti, Akola Kranti, Phule Revati and Phule Vasuda were procured from Sorghum Research Station Parbhani, Maharashtra. Refined vegetable oil, papad khar and spice mix were procured from local market for preparation of sorghum papad. Chemicals (analytical grade) and glass wares required during experiments were used from laboratory. Equipments and machineries like domestic mixer (for grinding of sorghum), texturometer (Stable Micro System TAXT2 plus), colour measuring instrument - Colorflex EZ, cabinet drier, microwave oven required in the present investigation were used, these equipments were available in College of Food Technology, Vasantrao Naik Marathwada Krushi Vidyapeeth, Parbhani.

\section{Physico-chemical analysis}

Physical Characteristics of Sorghum varieties like geometric mean diameter (GMD) (Gürsoy and Güzel, 2010), 1000 kernel weight of sorghum grains (W1000), bulkd density (BD) (AOAC, International 1990), true density $(\rho t)$, porosity $(\varepsilon)$ were determined with the help of different formulae for respective parameter.

\section{Preparation of papad}

Sorghum batter and water were used for preparing sorghum papad. Papadkhar was added to sorghum batter before batter was added to boiling water. Water was allowed to boil in a aluminium vessel and the batter was added to the boiling water coupled with stirring. The cooking process continues for 10 min with continuous stirring; the vessel was removed from the fire. Cooked slurry was poured onto a moist cotton cloth and spread it to $10 \mathrm{~cm}$ diameter with $2 \mathrm{~mm}$ thickness and allowed for drying.

\section{Physical quality attributes of raw and fried sorghum papad}

Total yield and number of sorghum papad

The total number of sorghum papad obtained from $100 \mathrm{~g}$ of different sorghum (Sorghum vulgare) varieties soaked for different durations were weighed and the total yield and number of sorghum papad were recorded. The raw sorghum papad prepared from different types of Sorghum varieties soaked for different durations were deep fried in refined sunflower oil at $180^{\circ} \mathrm{C} \pm 5^{\circ} \mathrm{C}$ were investigated to different quality attributes.

\section{Unit weight of raw and fried sorghum papad}

The unit weight of raw and fried sorghum papad of different sorghum varieties soaked for different durations were recorded by taking the weight of 10 sorghum papad.

\section{Diameter of raw and fried sorghum papad}

The diameter of raw and fried sorghum papad of different sorghum varieties and soaked for different durations were measured on opposite ends with the help of thread and recorded.

\section{Expansion percentage of fried sorghum papad}

The expansion percentage of fried sorghum papad was calculated according to the procedure of Vidyavati et al., (2004).

$\operatorname{Expansion}(\%)=\frac{\mathrm{DF}-\mathrm{DR}}{\mathrm{DR}} \times 100$ 
Where, $\mathrm{DF}=$ diameter of fried papad; DR = diameter of raw papad;

Major chemical characteristics of sorghum varieties and papad such as moisture (AOAC, International 1990), ash (AOAC, International 1990), fat (AOAC, International 1990), protein (AOAC, International 1990) and total carbohydrate (Pearson, 1976) were determined along with minerals like calcium and iron (Raghuramulu et al., 2003).

\section{Statistical analysis}

The data were analyzed for difference of significance by ANOVA used CRD and CD values are presented.

\section{Results and Discussion}

\section{Visual parameters of sorghum cultivars}

The samples were compared with Munsell colour chart and colour was represented in the values of hue, value and chroma. Colour of Parbhani Moti, Parbhani Jyoti, Phule Vasuda, Akola Kranti, Phule Revati were pearly white(5Y 8/2), creamy white(5Y 7/2), dull white(10YR 8/2), pale yellow(10YR 7/2) and pearly white(10YR 6/2) respectively. In sorghum phenolic compounds, particularly anthocyanins and condensed tannins are major contributors of colour of the grains (Awika and Rooney 2004). Results were nearer to the results physico-chemical properties of sorghum genotypes reported by Jambamma et al., (2011) (Table 1).

\section{Physical properties of sorghum cultivars}

The highest thousand kernel weight (34.30g) and thousand kernel volume $(28.5 \mathrm{ml})$ was observed for Parbhani Moti. Whereas the lowest thousand kernel weight (33.1g) and thousand kernel volume $(18.5 \mathrm{ml})$ was observed in Parbhani Jyoti and Akola Kranti respectively. This variation may be due to genotypic differences. The weight of thousand kernals is influenced by meteorological factors, methods of farming and genotypic differences (Liman et al., 2012). True density is an index of floury and corneous endosperm ratio inside the kernels. Higher the density indicates hardness of the grain (Rooney and Miller, 1982). The true density of Akola Kranti (as 1.8 $\mathrm{g} / \mathrm{ml}$ ) was found to be highest while Parbhani Moti reported lowest one $(1.2 \mathrm{~g} / \mathrm{ml})$. Akola Kranti had recorded highest bulk density (0.9 $\mathrm{g} / \mathrm{ml}$ ) while Parbhani Moti reported lowest one $(0.6 \mathrm{~g} / \mathrm{ml})$. No significant difference in the value of angle of repose was observed among the cultivars. The obtained values for physical properties recorded in the present study are in line with findings of Vannalli et al., (2008) (Table 2).

\section{Nutritional composition of sorghum varieties}

Moisture content was range from 12 to 13.9 per cent, fat (3.8 to 4.71 per cent), protein ( 9.8 to 15.08 per cent), carbohydrate (65.8 to 70.52 per cent) and ash content was ranged from 1.89 to 2.06 per cent.

The variation in per cent chemical composition might be due to variation in recipe. Statistically results were found to be significant at $\mathrm{CD}$ at 5 per cent. Similar range of per cent chemical composition was reported by Chavan et al., (2009) and Jambamma et al., (2011) (Table 3).

\section{Physical quality attributes of raw sorghum papad}

\section{Total yield of sorghum papad}

The highest yield of papad was observed for Phule Revati soaked for three days (80.5 g) and lowest for Parbhani Jyoti papad soaked for five days $(72.4 \mathrm{~g})$. This is mainly due to the separation of bran along with the adhered 
residual starch during preparation of batter from soaked whole cereal and millets grains. Similar results were good accordance with results reported by Manan et al., (1993) (Table 4).

\section{Number of sorghum papad}

The number of papad obtained was highest in one day soaked grains (17.8) followed by three days (17) and five days soaked grains (16.1). In the interaction effect the number of papad obtained from different varieties of sorghum grains soaked for different duration was significant at five per cent level.

\section{Unit weight of raw sorghum papad}

The highest weight $(5.5 \mathrm{~g})$ was observed in Phule Revati papad prepared by five days soaked grains lowest was in Phule Vasuda papad prepared from one day soaked grains $(3.92 \mathrm{~g})$. Increase water uptake by the severely damaged starch granules of five days soaked grains may be the reason for increased diameter. Soaked grains of one day were slightly hard to grind so the internal damage was less (Manan et al., 1993).

\section{Diameter of raw sorghum papad}

The diameter of raw papad ranged from 8.1 to $8.2 \mathrm{~cm}$ with a mean of $8.1 \mathrm{~cm}$. The diameter of the Parbhani Jyoti papad was significantly highest $(8.2 \mathrm{~cm})$ followed by Phule Revati $(8.13 \mathrm{~cm})$. Similarly the increase in the diameter of papad prepared from cereals soaked for five days may be due to the increased water uptake by the ruptured granules of starch during steaming (Srilakshmi, 2006).

The wide variation in the total yield, number of papads, unit weight and diameter of raw and fried papad among the sorghum varieties may be attributed to the variation in chemical composition, nature of starch, their characteristic shape, size and cooking behavior of the starch present in them depending upon the plant from which they are derived (Hadimani and Malleshi, 1993 and Srilakshmi, 2006).

\section{Physical quality attributes of fried sorghum papad}

\section{Weight of fried papad}

The weight of fried papad ranged from 5.24 to $6.29 \mathrm{~g}$ with mean value of $5.76 \mathrm{~g}$. Among the sorghum varieties, significantly highest weight of fried papad was observed in Phule Revati (6.29 g) and lowest was in Phule Vasuda papad (5.24 g) (Table 5).

Fig.1 Mean sensory score values for the sorghum papad prepared from 3 days soaked grains

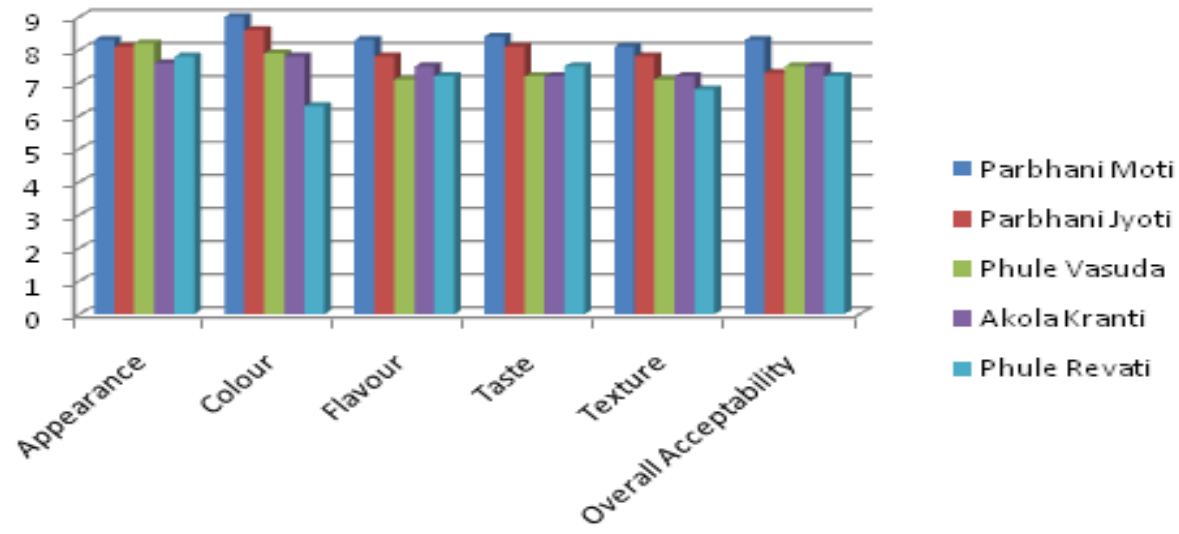


Table.1 Visual properties of sorghum

\begin{tabular}{|c|c|c|c|c|}
\hline \multirow{2}{*}{$\begin{array}{c}\text { Sr. } \\
\text { No. }\end{array}$} & \multirow[t]{2}{*}{ Cultivars } & \multicolumn{3}{|c|}{ Visual parameters of grain } \\
\hline & & Colour & Muncell notation for colour & Shape \\
\hline 1. & $\begin{array}{l}\text { Parbhani } \\
\text { Moti }\end{array}$ & Pearly white & $5 Y 8 / 2$ & Very bold \\
\hline 2. & $\begin{array}{l}\text { Parbhani } \\
\text { Jyoti }\end{array}$ & $\begin{array}{l}\text { Creamy } \\
\text { white }\end{array}$ & $5 Y 7 / 2$ & Bold \\
\hline 3. & Phule Vasuda & Dull white & $10 \mathrm{YR} 8 / 2$ & Round \\
\hline 4. & Akola Kranti & Pale yellow & 10YR $7 / 2$ & Bold \\
\hline 5. & Phule Revati & Pearly white & 10YR 6/2 & Round \\
\hline
\end{tabular}

Table.2 Physical properties of sorghum

\begin{tabular}{lcccccc}
\hline \multicolumn{1}{c}{ Grains } & $\begin{array}{c}\text { Thousand } \\
\text { Kernels } \\
\text { Weight }(\mathbf{g})\end{array}$ & $\begin{array}{c}\text { Kernel Size } \\
\text { G.M.D } \\
(\mathbf{m m})\end{array}$ & $\begin{array}{c}\text { Thousand } \\
\text { Kernel } \\
\text { volume }(\mathbf{m l})\end{array}$ & $\begin{array}{c}\text { True } \\
\text { Density } \\
(\mathbf{g} / \mathbf{m l})\end{array}$ & $\begin{array}{c}\text { Bulk } \\
\text { Density } \\
(\mathbf{g} / \mathbf{m l})\end{array}$ & $\begin{array}{c}\text { Angle of } \\
\text { Repose } \\
\text { (Degrees) }\end{array}$ \\
\hline Parbhani Moti & 34.3 & 3.81 & 28.5 & 1.2 & 0.60 & $32^{\circ} 42^{\prime}$ \\
Parbhani Jyoti & 33.1 & 4.08 & 23 & 1.4 & 0.70 & $32^{\circ} 11^{\prime}$ \\
Phule Vasuda & 34.1 & 3.91 & 26 & 1.3 & 0.65 & $30^{\circ} 15^{\prime}$ \\
Akola Kranti & 34.2 & 4.02 & 18.5 & 1.8 & 0.90 & $31^{\circ} 12^{\prime}$ \\
Phule Revati & 34.2 & 3.73 & 24 & 1.3 & 0.65 & $30^{\circ} 12^{\prime}$ \\
SE \pm & 0.1105 & 0.0270 & 0.129 & 0.0577 & 0.0624 & - \\
CD at 5\% & 0.3331 & 0.08161 & 0.3890 & 0.1739 & 0.1882 & - \\
\hline
\end{tabular}

Note: Each value is a mean of three determinations

Table.3 Nutritional composition of sorghum varieties

\begin{tabular}{cccccc}
\hline Particulars & $\begin{array}{c}\text { Moisture } \\
\text { Per cent }\end{array}$ & $\begin{array}{c}\text { Fat } \\
\text { Per cent }\end{array}$ & $\begin{array}{c}\text { Protein } \\
\text { Per cent }\end{array}$ & $\begin{array}{c}\text { Carbohydra } \\
\text { te } \\
\text { Per cent }\end{array}$ & $\begin{array}{c}\text { Ash } \\
\text { Per } \\
\text { cent }\end{array}$ \\
\hline Parbhani Moti & 12 & 4.04 & 15.08 & 66.77 & 2.06 \\
Parbhani Jyoti & 13.5 & 3.9 & 14.7 & 65.8 & 2 \\
Phule Vasuda & 13.8 & 4.71 & 9.95 & 69.54 & 1.9 \\
Akola Kranti & 13.03 & 3.8 & 13.9 & 67.33 & 1.94 \\
Phule Revati & 13.9 & 3.89 & 9.8 & 70.52 & 1.89 \\
SE \pm & 0.3631 & 0.0410 & 0.0472 & 0.0411 & 0.2396 \\
CD at 5\% & 1.0943 & 0.1236 & 0.1424 & 0.1241 & 0.7222 \\
\hline
\end{tabular}

Note: Each value is a mean of three determinations 
Table.4 Physical characteristics of raw papad prepared from different Sorghum varieties soaked for different durations

\begin{tabular}{|c|c|c|c|c|c|c|c|c|c|c|c|c|c|c|c|c|}
\hline \multirow{3}{*}{$\begin{array}{c}\text { Sorghum } \\
\text { Variety }\end{array}$} & \multirow{2}{*}{\multicolumn{4}{|c|}{ Total yield of papad (g) }} & \multicolumn{4}{|c|}{ Number of papad } & \multicolumn{4}{|c|}{ Unit weight (g) } & \multicolumn{4}{|c|}{ Diameter $(\mathrm{cm})$} \\
\hline & & & & & & & & of soal & ing (days & & & & & & & \\
\hline & 1 & 3 & 5 & $\mathbf{M}$ & 1 & 3 & 5 & $\mathbf{M}$ & 1 & 3 & 5 & $\mathbf{M}$ & 1 & 3 & 5 & $\mathbf{M}$ \\
\hline $\begin{array}{c}\text { Parbhani } \\
\text { Moti }\end{array}$ & 79 & 79.5 & 72.5 & 77 & 18.5 & 17.4 & 16.6 & 17.5 & 4.01 & 4.45 & 5 & 4.4 & 8.05 & 8.18 & 8.35 & 8.1 \\
\hline $\begin{array}{l}\text { Parbhani } \\
\text { Jyoti }\end{array}$ & 78.9 & 79.4 & 72.4 & 76.9 & 18 & 17.1 & 16.3 & 17.1 & 4.1 & 4.5 & 4.9 & 4.5 & 8.1 & 8.2 & 8.3 & 8.2 \\
\hline $\begin{array}{l}\text { Phule } \\
\text { Vasuda }\end{array}$ & 79.8 & 80.2 & 75.5 & 78.5 & 18.6 & 17.5 & 16.1 & 17.4 & 3.92 & 4.2 & 4.7 & 4.2 & 8.02 & 8.12 & 8.3 & 8.1 \\
\hline $\begin{array}{l}\text { Akola } \\
\text { Kranti }\end{array}$ & 79 & 79.5 & 74.3 & 77.6 & 17.4 & 16.9 & 16.1 & 16.8 & 4.8 & 4.9 & 5.3 & 5 & 8.04 & 8.14 & 8.35 & 8.1 \\
\hline $\begin{array}{l}\text { Phule } \\
\text { Revati }\end{array}$ & 80 & 80.5 & 75 & 78.5 & 16.9 & 16.1 & 15.8 & 16.2 & 4.85 & 4.99 & 5.5 & 5.1 & 8 & 8.1 & 8.29 & 8.13 \\
\hline Mean & 79.3 & 79.8 & 73.9 & 77.7 & 17.8 & 17 & 16.1 & 17 & 4.3 & 4.6 & 5 & 4.6 & 8 & 8.1 & 8.3 & 8.1 \\
\hline $\mathrm{SE} \pm$ & 0.3679 & 0.0577 & 0.2670 & - & 0.2633 & $\begin{array}{c}0.05 \\
77\end{array}$ & $\begin{array}{c}0.05 \\
77\end{array}$ & - & 0.0367 & 0.0448 & $\begin{array}{c}0.26 \\
33\end{array}$ & - & $\begin{array}{c}0.25 \\
95\end{array}$ & $\begin{array}{c}0.03 \\
67\end{array}$ & $\begin{array}{c}0.03 \\
67\end{array}$ & \\
\hline $\mathrm{CD}$ at $5 \%$ & 1.1336 & 0.1779 & 0.823 & - & 0.8114 & & & - & 0.1133 & 0.1382 & $\begin{array}{c}0.81 \\
14\end{array}$ & - & $\begin{array}{c}0.79 \\
97\end{array}$ & $\begin{array}{c}0.11 \\
33\end{array}$ & $\begin{array}{c}0.11 \\
33\end{array}$ & \\
\hline
\end{tabular}

Note: Each value is a mean of three determinations

Table.5 Physical characteristics of fried papad prepared from different

Sorghum varieties soaked for different durations

\begin{tabular}{cccccccccccccc}
\hline $\begin{array}{c}\text { Sorghum } \\
\text { Variety }\end{array}$ & \multicolumn{4}{c}{ Unit weight $(\mathbf{g})$} & \multicolumn{4}{c}{ Diameter (cm) } & \multicolumn{5}{c}{ Expansion per cent (\%) } \\
& $\mathbf{1}$ & $\mathbf{3}$ & $\mathbf{5}$ & $\mathbf{M}$ & $\mathbf{1}$ & $\mathbf{3}$ & $\mathbf{5}$ & $\mathbf{M}$ & $\mathbf{1}$ & $\mathbf{3}$ & $\mathbf{5}$ & $\mathbf{M}$ \\
\hline Parbhani Moti & 4.82 & 5.51 & 6.17 & 5.5 & 9.52 & 10.42 & 10.51 & 10.15 & 18.26 & 27.38 & 25.86 & 23.83 \\
Parbhani Jyoti & 5.35 & 5.58 & 6.04 & 5.65 & 9.48 & 10.29 & 10.4 & 10.06 & 17.03 & 25.48 & 25.3 & 22.6 \\
Phule Vasuda & 4.74 & 5.2 & 5.8 & 5.24 & 9.34 & 10.05 & 10.25 & 9.88 & 16.45 & 23.76 & 23.49 & 21.23 \\
Akola Kranti & 5.82 & 6.07 & 6.54 & 6.14 & 9.37 & 10.15 & 10.28 & 9.93 & 16.54 & 24.69 & 23.11 & 21.45 \\
Phule Revati & 5.93 & 6.18 & 6.78 & 6.29 & 9.32 & 10.1 & 10.2 & 9.87 & 16.5 & 24.69 & 23.03 & 23.86 \\
Mean & 5.18 & 5.71 & 6.27 & 5.76 & 9.41 & 10.2 & 10.33 & 9.98 & 17.07 & 25.2 & 24.16 & 22.94 \\
SE \pm & 0.01 & 0.02 & 0.03 & - & .005 & 0.02 & 0.05 & - & 0.02 & .005 & 0.02 & - \\
CD at 5 \% & 0.03 & 0.08 & 0.12 & - & 0.01 & 0.08 & 0.17 & - & 0.08 & 0.01 & 0.08 & - \\
\hline
\end{tabular}

Note: Each value is a mean of three determinations

Table.6 Nutritional composition of raw sorghum papad

\begin{tabular}{ccccccc}
\hline Sr No. & $\begin{array}{c}\text { Papad prepared } \\
\text { from sorghum } \\
\text { variety }\end{array}$ & $\begin{array}{c}\text { Moisture } \\
\text { Per cent }\end{array}$ & $\begin{array}{c}\text { Fat } \\
\text { Percent }\end{array}$ & Protein Per cent & $\begin{array}{c}\text { Carbohydrate } \\
\text { Per cent }\end{array}$ & $\begin{array}{c}\text { Ash } \\
\text { Per cent }\end{array}$ \\
\hline 1 & Parbhani Moti & 9 & 1.05 & 12.64 & 76.77 & 0.54 \\
2 & Parbhani Jyoti & 9.6 & 0.93 & 11.93 & 76.95 & 0.59 \\
3 & Phule Vasuda & 9.3 & 1.12 & 8.09 & 80.93 & 0.56 \\
4 & Akola Kranti & 9.5 & 0.9 & 11.3 & 77.73 & 0.57 \\
5 & Phule Revati & 9.05 & 0.92 & 7.97 & 81.5 & 0.56 \\
& Mean & 9.29 & 0.98 & 10.38 & 78.77 & 0.56 \\
& SE \pm & 0.0517 & 0.0263 & 0.0269 & 0.0628 & .005 \\
& CD at 5 \% & 0.1593 & 0.0811 & 0.0831 & 0.1936 & .017 \\
\hline
\end{tabular}

Note: Each value is a mean of three determinations 
Table.7 Mean sensory score values for the sorghum papad Prepared from three days soaked grains

\begin{tabular}{ccccccc}
\hline $\begin{array}{c}\text { Sorghum } \\
\text { variety }\end{array}$ & Appearance & Colour & Flavour & Taste & Texture & $\begin{array}{c}\text { Overall } \\
\text { Acceptability }\end{array}$ \\
\hline Parbhani Moti & 8.3 & 9 & 8.3 & 8.4 & 8.1 & 8.3 \\
Parbhani Jyoti & 8.1 & 8.6 & 7.8 & 8.1 & 7.8 & 7.3 \\
Phule Vasuda & 8.2 & 7.9 & 7.1 & 7.2 & 7.1 & 7.5 \\
Akola Kranti & 7.6 & 7.8 & 7.5 & 7.2 & 7.2 & 7.5 \\
Phule Revati & 7.8 & 6.3 & 7.2 & 7.5 & 6.8 & 7.2 \\
Mean & 8 & 7.92 & 7.58 & 7.68 & 7.4 & 7.56 \\
SE \pm & 0.0577 & 0.2633 & 0.0576 & 0.057 & 0.0714 & 0.0577 \\
CD at 5 \% & 0.1779 & 0.8114 & 0.1878 & 0.178 & 0.2203 & 0.1779 \\
\hline
\end{tabular}

Note: Each value is a mean of three determinations

\section{Diameter of fried papad}

The highest diameter was observed in Parbhani Moti papad soaked for five days $(10.51 \mathrm{~cm})$ and lowest was in Phule Revati papad soaked for one day $(9.32 \mathrm{~cm})$. A definite pattern of total amylose and hot water insoluble amylose contents may be related to better expansion of cereals and millets (Kotagi, 2002).

\section{Expansion per cent of fried papad}

The highest expansion per cent was observed in Parbhani Moti soaked for three days (27.38) and lowest was in Phule Revati papad soaked for one day (16.5).

The expansion per cent increase in papad during frying may be due to the replacement of moisture by oil due to the higher content of water insoluble amylase (Chinnaswamy and Bhattarcharya, 1986).

\section{Nutritional composition of raw sorghum papads}

The data pertaining to the chemical composition of sorghum papad prepared samples from different sorghum varieties was as follows, moisture content was range from 9 to 9.6 per cent, fat (0.9 to 1.12 per cent), protein ( 7.97 to 12.64 per cent), carbohydrate (76.77 to 81.5 per cent) and ash (0.54 to 0.59 per cent) (Table 6).

\section{Organoleptic evaluation of sorghum papads}

Mean appearance scores ranged from 7.6 to 8.3 with a mean of 8 . Parbhani Moti papad scored highest (8.3) followed by Phule Vasuda (8.2) and Parbhani Jyoti papad (8.1). Mean colour scores ranged from 6.3 to 9.0 with a mean of 7.92. Parbhani Moti papad scored highest (8.3) followed by Parbhani Jyoti papad (8.6). The least score was obtained for Phule Revati (6.3).

The Parbhani Moti papad scored highest (8.1) followed by Parbhani Jyoti (7.80). The lowest was in Phule Revati papad (6.8). The overall acceptability score ranged from 7.2 to 8.3 with a mean of 7.56. Parbhani Moti papad scored highest (8.3) followed by Phule Vasuda (7.5) and Akola Kranti (7.5). The least was in Phule Revati papad (7.2). The result of present study was in good 
accordance with results reported by Nazni and Pradheepa 2010.

\section{Changes in sensory attributes of fried sorghum papads}

As the duration of soaking of grains increased there was development of off flavour in the fried papad. Papad prepared from five days soaked grains developed very mild off flavour. The result of changes in sensory attributes of fried Sorghum papads was in good accordance with results reported by Venkatesh et al., (1970). The textural changes in papad were attributed to the increased surface area by carbon dioxide liberated from Papad Khar during frying (Chowdhury et al., 2009). The result of comparison of sorghum papad with black gram \& finger millet papads was in good accordance with Shwetha et al., (2009) (Table 7 and Fig. 1).

It can be concluded from above discussion that three days soaking period for sorghum grains is suitable for papad making. Out of five cultivars of sorghum on the basis of physical parameters, sensory characteristics and yield of papad Parbhani Moti cultivar found most suitable for papad preparation by conventional method.

\section{References}

AOAC. International, 1990. Official methods of analysis. Trends Food Sci. Technology. Association of Official Analytical Chemists, Washington DC, USA. AOAC. 2004.

Anglani, C. (1998). Sorghum for human food: a review. Plant Foods Human Nutrition. 52: $85-89$.

Anonymous (2012). ICRISAT report 2012. www.icrisat.org.

Anonymous (2013). Economic Survey of India (2012-13). Statistical Appendix. Production of Major crops. Government of India. Link: http://indiabudget.nic.in.

Arya, S.S. (1990). Grain based snack and convenience foods. Indian Food Packer, 44 (5): 17- 38.

Awika, J.M. and Rooney L.W. (2004). Sorghum phytochemicals and their potential aspects on human health. Phytochemistry, 65:1199-1221.

Awika, J.M., Rooney L.W., Waniska R.D. (2004). Properties of 3Deoxyanthocyanins from sorghum. Journal of Agricultural and Food Chemistry 52:4388-4399.

Bogue, J. and Sorenson D. (2008). The Marketing of Gluten-free Cereal Products. Gluten-free Cereal Products and Beverages, Elsevier Inc, New York, pp. 393e412.

Chavan, U. D., Patil J.V., Shinde M.S. (2009). Nutritional and Roti quality of sorghum genotypes. Indonesian Journal of Agricultural Science 10(2), 80-87.

Chinnaswamy, R. and Bhattacharya, K.R., (1986) Characteristics of gelchromatographic factions of starch in relation of rice and expanded rice product qualities. Starch/Strake, 38: 5157

Chowdhury, M. G. F., Miaruddin M., Rahman M. M., Islam M. S. and Tariqul Islam A. F. M. (2009). Study on the Effect of Preservative on the Storage Quality of Spiced Papads. j. innov.dev.strategy 2(3): 30-33.

FAO. 1995. Sorghum and millets in human nutrition. FAO Food and nutrition Series No. 27. Rome, Italy: FAO.64 pp.

Gürsoy, S. and Güzel E. (2010). Determination of Physical Properties of Some Agricultural Grains. Research Journal of Applied Sciences, Engineering and Technology 2(5): 492 498.

Hadimani, N.A. and Malleshi, N.G., (1993). Studies on milling, physico-chemical 
properties, nutrient composition and dietary fibre content of millets. J. Food Sci. Technol., 30:17-20.

Jambamma, Imaya Kumari, A. and Kailappan, R. (2011). Study of PhysicoChemical Properties of food grain sorghum and product ready-to-cook mix from sorghum. International Journal of Recent Scientific Research. Vol. 1, Issue, 3, pp. 96-99.

Kotagi, M., (2002). Varietal suitability of rice for conventional processing. M.H.Sc. Thesis, Univ. Agric. Sci., Dharwad.

Liman L., Thomas J. H., Donghai W., Jeff D. W., and Scott R.B. (2012). Characterization of sorghum grain and evaluation of sorghum flour in a Chinese egg noodle system. Journal of Cereal Science, 55: 31-36.

Manan, J.K., Kulkarni, S.G. and Shukla, J.C., (1993). Studies on preparation, packaging and storage of wheat papads. Beverage Food World, pp.1022.

Nazni, P. and Pradheepa S. (2010). Physicochemical analysis and organoleptic evaluation of papads prepared from jowar millet flour. International Journal of Current Research. Vol. 3, pp. 033-037.

Pearson, D.1976.The Dictionary of Nutrition and Food Technology. Fifth edition. Butter Worth Publisher, London.

Raghuramulu N, Nair MK \& Kalyansundaram S (2003). A Manual of
Laboratory Techniques, National Institute of Nutrition, ICMR, Jamai-Osmania, Hyderabad, India.

Shakuntala, N., Shadaksharaswamy, M. (2001). Food: Facts And Principles, Second Edition, New Age International (P) Ltd. Publishers, pp.243-247.

Shwetha Kamat., Nirmala Yenagi and Shobha Naganur. (2009). Consumption pattern of papad at household level and its availability in the local market. Karnataka J. Agric. Sci., 22(2):399-403.

Srilakshmi, B. (2006). Food Science, Third Edition, New Age International (P) Ltd. Publishers, pp.1-66.

Vanithasri.J, Kanchana.S, Hemalatha.G, Vanniarajan.C and Sahulhameed.M. (2012). Mole of millets and its importance in new millennium. International Journal of Food Science \& Technology.Vol.2, (1). 35-47.

Vannalli S.B., Kasturiba R., K. Naik and Nirmala V. (2008). Nutritive Value and Quality Characteristics of Sorghum Genotypes. Karnataka Journal of Agricultural Science, 20(3):586-588.

Veena, B., Reddy B. S. and Sunand Sharan. (2012). Effect of Incorporation of Soy Flour on the Quality of Papad. Journal of Biology, Agriculture and Healthcare Vol. 2, No.5.

Vidyavati, H.G., Mushtari, J., Vijayakumari, J., Gokani, S.S. and Begum, S. (2004). Utilization of finger millet in the preparation of papad. J. Food Sci. Tech., 41: 379-382.

\section{How to cite this article:}

Butti Prabhakar, D.R. More, P. Srilatha and Chavan Ramesh Fulchand. 2017. Screening of Sorghum Varieties for Papad Preparation. Int.J.Curr.Microbiol.App.Sci. 6(7): 1116-1124. doi: https://doi.org/10.20546/ijcmas.2017.607.135 